\title{
PENGARUH BERBAGAI MACAM MULSA TERHADAP PERTUMBUHAN DAN HASIL BAWANG MERAH DI ULTISOL KABUPATEN BUNGO
}

\author{
M. Faisal*, Gusni Yelni** \\ *Alumnus Program Studi Agroteknologi Fakultas Pertanian UMB \\ ** Dosen Program Studi Agroteknologi Fakultas Pertanian UMB
}

Artikel Diterima 18 November 2020, disetujui 10 Januari 2021

ABSTRAK

Penelitian ini dilaksanakan di Kebun Percobaan Fakultas Pertanian Universitas Muara Bungo (UMB) Sungai Binjai Km.06 Kecamatan Bathin III dengan ketinggian \pm 101 meter di atas permukaan laut. Penelitian ini dilaksanakan dari bulan Mei 2018 - Agustus 2018. Penelitian ini bertujuan untuk mengetahui pengaruh penggunaan mulsa dan terhadap pertumbuhan bawang merah dan mendapatkan penggunaan mulsa manakah yang lebih efesien dan efektif bagi tanaman bawang merah

Penelitian ini didesain berdasarkan Rancangan Acak Kelompok (RAK), dengan 5 perlakuan dan 4 kelompok dengan pemberian berbagai macam Mulsa pada tanah Ultisol yaitu : M0 (Tanpa Pemberian Mulsa, M1(Pemberian Mulsa Jerami Padi), M2 (Pemberian Mulsa Kerinyu), M3 (Pemberian Mulsa Plastik Transparan) dan M4 (Pemberian Mulsa Hitam Perak). Pengamatan yang diamati dalam penelitian ini adalah tinggi tanaman $(\mathrm{cm})$, jumlah daun (helai), jumlah anakan perumpun (Helai), Bobot basah umbi perumpun (gram) dan Bobot Umbi perhektar (ton/ha). Untuk melihat pengaruh perlakuan terhadap peubah yang diamati maka data diperoleh dianalisis secara statistik, menggunakan sidik ragam dan untuk melihat perbedaan antara perlakuan dilanjutkan dengan Duncan New Multiple Range Test (DNMRT) pada tarif nyata 5\%.

Hasil penelitian menunjukkan bahwa Penggunaan berbagai macam mulsa berpengaruh tidak nyata terhadap semua parameter yang diamati yaitu : tinggi tanaman $(\mathrm{cm})$, jumlah daun (helai), jumlah anakan perumpun (anakan), bobot basah umbi perumpun (gram) dan bobot umbi per hektar (Ton/ha) tanaman bawang daun. Belum ditemukan jenis mulsa yang terbaik untuk pertumbuhan hasil tanaman bawang merah.

Kata Kunci : Bawang Merah, Mulsa, Pertumbuhan dan Hasil

\section{PENDAHULUAN}

Bawang merah merupakan
salah satu komoditas sayuran unggulan yang sejak lama telah diusahakan oleh petani secara intensif. Hal ini karena bawang merah memiliki nilai ekonomi yang cukup tinggi. Meskipun minat petani terhadap bawang merah cukup kuat namun dalam proses pengusahaannya masih ditemui berbagai kendala, baik kendala yang bersifat teknis maupun ekonomis (Sumarni dan Hidayat, 2005).

Berdasarkan deskripsi botaninya, tanaman bawang merah memiliki potensi produktivitas yang berada di atas 20 ton/ha, namun di lapangan produksi bawang merah 
rata-rata jauh lebih rendah dari potensi hasilnya. Produksi bawang merah di Provinsi Jambi tahun 2016 meningkat sebesar 4,836 juta ton, dibandingkan tahun 2015 sebesar 3,937 juta ton.(Badan Pusat Statistik Jambi, 2016).

Salah satu faktor yang mempengaruhi produksi bawang merah ditanah Ultisol Kabupaten Bungo adalah kondisi tanah yang kurang unsur hara akibat tanah $(\mathrm{pH}$ rendah) maka diperlukan upaya penerapan teknologi yang sesuai untuk meningkatkan hasil produksi bawang merah, teknologi yang dapat diterapkan dalam budidaya bawang merah akibat tanah yang kekurangan unsur hara adalah pemakaian mulsa.

Tanah yang akan digunakan pada penelitian ini merupakan Ultisol, Kandungan hara pada Ultisol umumnya rendah karena pencucian basa berlangsung intensif, sedangkan kandungan bahan organik rendah karena proses dekomposisi berjalan cepat dan sebagian terbawa erosi. Pada Ultisol yang mempunyai horizon kandik, kesuburan alaminya hanya bergantung pada bahan organik di lapisan atas. Dominasi kaolinit pada tanah ini tidak member kontribusi pada kapasitas tukar kation tanah, sehingga kapasitas tukar kation hanya bergantung pada kandungan bahan organik dan fraksi liat. Oleh karena itu, peningkatan produktivitas Ultisol dapat dilakukan melalui perbaikan tanah (ameliorasi), pemupukan, dan pemberian bahan organik (Prasetyo dan Suriadikarta, 2006). Provinsi Jambi memiliki potensi lahan kering Ultisol seluas 2.272.725 hektar $(42,53 \%$ dari luas daratannya yaitu 5.016.005 hektar), (Dinas Pertanian Tanaman Pangan Provinsi Jambi, 2016)
Penggunaan mulsa telah lama digunakan oleh masyarakat petani di Indonesia, baik itu mulsa organik maupun anorganik. Penggunaan mulsa hitam perak dari sekian banyak penelitian yang dilakukan mampu memberikan hasil yang sangat menguntungkan. Namun, mengalami kelemahan yaitu untuk berlindungnya hama di bawah mulsa dan mengakibatkan tanaman terserang penyakit busuk akar disebabkan suhu di bawah permukaan plastik stabil dan lembab. Upaya mengurangi penyakit busuk akar dapat dilakukan dengan menggunakan mulsa plastik trans-paran.

Mulsa plastik transparan bersifat meneruskan sinar datang yang di sekap di bawah plastik kemudian diteruskan sehingga mampu mengaktifkan mikroorganisme di dalam tanah. Suhu panas yang diciptakan mampu membunuh hama yang berlindung di bawah plastik serta mengurangi serangan penyakit busuk akar, dan diharapkan penggunaan mulsa transparan memberikan hasil umbi bawang yang lebih besar. Mulsa Jerami memiliki efek menurunkan suhu tanah, mengkonservasi tanah dengan menekan erosi dan dapat menghambat pertumbuhan tanaman pengganggu (Chairumansyah : 2010)

Penelitin ini bertujuan untuk mengetahui pengaruh penggunaan mulsa yang lebih efesien dan efektif bagi tanaman bawang merah. Hasil penelitian Syarfianda (2015) Pertumbuhan dan hasil tanaman bawang merah terbaik dijumpai pada mulsa kirinyuh. Terdapat interaksi yang nyata antara perlakuan mulsa kirinyuh terhadap potensi hasil (ton/ha) tanaman bawang merah.

Hasil penelitian Wisudawati (2012) pada tanaman bawang merah 
menunjukkan bahwa pemberian mulsa jerami padi dan mulsa plastik hitam dapat meningkatkan bobot segar umbi per hektar masingmasing 29,3\% dan 24,7 \% dibanding tanpa mulsa. Berdasarkan uraian diatas maka penulis tertarik melakukan penelitian dengan judul : "Pengaruh Berbagai Macam Mulsa Terhadap Pertumbuhan Dan Hasil Bawang Merah Di Ultisol Kabupaten Bungo"

\section{MATERI DAN METODA}

Penelitian ini dilaksanakan di Kebun Percobaan Fakultas Pertanian Universitas Muara Bungo (UMB) Sungai Binjai Km.06 Kecamatan Bathin III dengan ketinggian \pm 101 meter di atas permukaan laut. Penelitian dilaksanakan dari bulan Juni 2018 - September 2018. Bahan - bahan yang digunakan adalah benih bawang merah, dolomit, jerami padi, kerinyu, plastik transparan, plastik hitam perak, dan pupuk kandang. Alat - alat yang digunakan adalah timbangan digital, gembor, sprayer, meteran, cangkul, label, alat tulis, tali rafia, bambu, sabit.

Penelitian ini merupakan penelitian percobaan dengan berbagai jenis mulsa yang didesain berdasarkan Rancangan Acak Kelompok (RAK), dengan 5 perlakuan dan 4 kelompok dengan pemberian berbagai macam Mulsa pada tanah Ultisol. Perlakuan dalam penelitian ini adalah : M0 (Tanpa Pemberian MulsA), M1 (Pemberian Mulsa Jerami Padi), M2 (Pemberian Mulsa Kerinyu), M3 (Pemberian Mulsa Plastik Transparan) dan M4 (Pemberian Mulsa Hitam Perak)

Setiap perlakuan dikelompokkan 4 kali sehingga terdapat 20 petak percobaan berukuran $105 \mathrm{~cm} \mathrm{x}$ $75 \mathrm{~cm}$ dengan jarak tanam $15 \times 15$ $\mathrm{cm}$ dan jarak antar bedengan yaitu 50 $\mathrm{cm}$ sehingga terdapat 35 tanaman yang nantinya tiap bedeng mewakili satu perlakuan, maka jumlah tanaman seluruhnya sebanyak 700 tanaman, tiap petak diambil 4 sampel, jadi jumlah tanaman sampel. Pengolahan tanah secara umum melakukan penggemburan dan pembuatan bedengan. Tahaptahap pengemburan yaitu : Pencangkulan untuk memperbaiki struktur tanah, Pemberian dolomite dengan dosis $0,312 \mathrm{~kg}$ setiap bedangan guna untuk memperbaiki fisik serta kimia tanah yang akan menambah kesuburan lahan yang akan kita gunakan. Bedengan dengan ukuran lebar $75 \mathrm{~cm}$ dan panjang dengan ukuran $105 \mathrm{~cm}$. Tinggi bedeng $20 \mathrm{~cm}$ dengan jarak antar bedeng $50 \mathrm{~cm}$, seminggu sebelum penanaman dilakukan pemupukan dengan dosis $0,8 \mathrm{~kg} /$ bedengan $=10$ ton/Ha. terlebih dahulu yaitu pupuk kandang setelah pengolahan tanah. Sedang jarak tanam dalam bedengan $15 \times 15 \mathrm{~cm}$. Pemberian berbagai macam mulsa dilakukan 7 hari sebelum tanam

Pemeliharaan dilakukan sejak bibit ditanam hingga panen yang meliputi, penyiraman, penyulaman, penyiangan, dan pembumbunan. Pemanenan bawang merah dilakukan pada saat tanaman berumur $65 \mathrm{hst}$ dengan ciri-ciri fisik daunnya sudah mulai layu serta menguning sekitar 70-80\% dari jumlah tanaman, pangkal batang mengeras, dan sebagian umbi telah tersembul di atas tanah.. Cara panen dilakukan dengan mencabut seluruh bagian tanaman. Pemanenan bawang merah dilakukan pada pagi hari. 
Adapun pengamatan yang dilakukan adalah berupa tinggi tanaman $(\mathrm{cm})$, Jumlah daun ( helai ) Jumlah anakan Per rumpun (Anakan), Bobot basah umbi per rumpun ( gram ), dan Bobot umbi perhektar (ton/ha). Untuk melihat pengaruh perlakuan terhadap peubah yang diamati maka data diperoleh dianalisis secara statistik, menggunakan sidik ragam dan untuk melihat perbedaan antara perlakuan dilanjutkan dengan Duncan New Multiple Range Test (DNMRT) pada tarif nyata $5 \%$.

\section{HASIL DAN PEMBAHASAN}

\section{Tinggi Tanaman (cm)}

Hasil analisis ragam menunjukkan bahwa berbagai macam mulsa berpengaruh tidak nyata terhadap tinggi tanaman (cm). Bawang Merah di tanah Ultisol. Rataan tinggi tanaman Bawang Merah pada masing-masing perlakuan pengaruh berbagai macam mulsa dapat dilihat pada Tabel 1 .

Tabel 1.Rataan Tinggi Tanaman (cm) Bawang Merah Pengaruh Berbagai Macam Mulsa di Tanah Ultisol

\begin{tabular}{|c|c|}
\hline Perlakuan & Rata-Rata $(\mathrm{cm})$ \\
\hline M0 & 44,97 \\
M1 & 48,59 \\
M2 & 46,19 \\
M3 & 46,34 \\
M4 & 45,41 \\
\hline KK = 5,38\% \\
\hline
\end{tabular}

Keterangan : Perlakuan tidak berpengaruh nyata terhadap tinggi tanaman $(\mathrm{cm})$ $(\mathrm{P}>0,05)$.

Berdasarkan Tabel 1 di atas dapat dilihat bahwa perlakuan berbagai macam berpengaruh tidak nyata terhadap tinggi tanaman bawang merah di tanah ultisol
( $P>0,05)$. Hal ini berarti bawang merah yang diberi berbagai mulsa maupun yang tanpa pemberian mulsa menunjukan pertumbuhan tinggi tanaman yang sama. Terjadinya hal ini diduga mulsa yang diberikan belum menunjukan peranannya seperti mempertahankan kelembaban tanah dan mempertahankan kesuburan tanah.

Sunanto (2008) menyatakan pemberian mulsa terhadap budidaya tanaman hanya berpengaruh fisik tidak memberi pengaruh kimia pada tanah. Sukirno (1993) dalam Samiati, $d k k$. . (2012) mengemukakan bahwa mulsa mempengaruhi iklim mikro melalui penerusan dan pemantulan cahaya matahari, suhu dan kelembaban di bawah dan di atas mulsa serta kadar lengas tanah. Lebih lanjut Gardner et al. (1991) nutrisi mineral dan ketersediaan air mempengaruhi pertumbuhan ruas pada organ vegetatif. Sedangkan Priatna (2012) menjelaskan bahwa ketersediaan hara tanah tidak hanya terjadi akibat meningkatnya aktivitas mikroorganisme tanah dalam melakukan proses dekomposisi bahan organik, tetapi juga terjadi melalui penekanan pencucian hara tanah sebagai akibat tertutupnya permukaan tanah.

Penelitian ini selaras dengan penelitian Ekowati, $d k k$ (2017) yang menyatakan bahwa mulsa plastik hitam perak dapat meningkatkan suhu udara sehingga kurang sesuai untuk pertumbuhan tanaman bawang merah. Ini dikarenakan permukaan perak memancarkan kembali sebagian besar radiasi matahari yang datang. Menurut hasil penelitian Mayun (2007) menunjukkan bahwa pemberian mulsa jerami tidak memberikan pengaruh nyata terhadap pertumbu- 
han bawang merah. Rendahnya nilai rata-rata tinggi tanaman bawang merah perlakuan mulsa disebabkan kondisi mulsa yang dapat menjadi sarang bagi hama S. exigua.

\section{Jumlah Daun (Helai )}

Berdasarkan hasil analisis ragam menunjukkan bahwa berbagai macam mulsa berpengaruh tidak nyata terhadap jumlah daun (helai). Bawang Merah di tanah Ultisol. Rataan jumlah daun tanaman Bawang Merah pada masing-masing perlakuan pengaruh berbagai macam mulsa dapat dilihat pada Tabel 2.

Tabel 2. Rataan Jumlah Daun (helai)

$\begin{array}{lrr}\text { Tanaman } & \text { Bawang } & \text { Merah } \\ \text { Pengaruh } & \text { Berbagai } & \text { Macam } \\ \text { Mulsa di Tanah Ultisol } & \end{array}$

\begin{tabular}{|c|c|}
\hline Perlakuan & $\begin{array}{c}\text { Rata-Rata } \\
\text { (helai) }\end{array}$ \\
\hline M0 & 13,31 \\
M1 & 13,94 \\
M2 & 13,31 \\
M3 & 13,00 \\
M4 & 12,69 \\
\hline KK =16,18\% \\
\hline
\end{tabular}

Keterangan : Perlakuan tidak berpengaruh nyata terhadap jumlah daun (helai) $(\mathrm{P}>0,05)$.

Dari Tabel 2 di atas dapat dijelaskn bahwa perlakuan berbagai macam berpengaruh tidak nyata terhadap jumlah daun bawang merah di tanah ultisol $(\mathrm{P}>0,05)$. Hal ini diduga karena mulsa tidak mampu mempertahankan kandungan bahan organik tanah sehingga menghambat pertambahan jumlah daun. Menurut Pramana (2012) pemberian mulsa terhadap budidaya tanaman kurang baik pada tanah yang memiliki tingkat kesuburan rendah dan mengandung beragam asam-asam organik yang sebagian bersifat racun bagi tanaman. Akibatnya pemberian mulsa hanya akan mengurangi kerja pencucian racun oleh air hujan atau air irigasi yang diberikan. Oleh karena itu pemberian mulsa pada tanah seperti gambut terlebih dahulu diperhatikan sifat-sifat dari gambut itu sendiri, sehingga tidak mengganggu proses pertumbuhan dan produksi tanaman.Pada pemberian mulsa . kelembahan tanah sama pada tanah baik yang diberikan mulsa maupun tanpa mulsa.

Rataan jumlah daun bawang yang dihasilkan pada penelitian yaitu berkisar 12,69 - 13,94 helai dan sangat rendah jika dibandikan dengan deskripsi tanaman yaitu 3447 helai, hal menunjukan bahwa tingkat kesuburan tanah penelitian rendah sehingga pembe-rian mulsa tidak efektif karena mulsa hanya mempengaruhi sifat fisik tanah. Hanhim (2014) juga menyatakan bahwa pemberian mulsa hanya akan berengaruh terhadap sifat fisik tanah terutama struktur tanah sehingga memperbaiki stabilitas agregat tanah. Teknologi permulsaan dapat mencegah evaporasi. Dalam hal ini air yang menguap dari permukaan tanah akan ditahan oleh bahan mulsa dan jatuh kembali ke tanah.

Penggunaan mulsa bertujuan untuk mengurangi penguapan dari permukaan tanah, menjaga kelembaban tanah dan sebagai sumber bahan organik tanah. Selain itu mulsa juga berperan sebagai pemantap tanah yaitu melindungi permukaan tanah dari pukulan butirbutir hujan secara langsung. Mulsa juga berperan mengendalikan suhu tanah sehingga kehilangan air dan kehilangan panas dari tanah dapat dihindarkan (Dariah, 2007). 


\section{Jumlah Anakan Perumpun (Anakan)}

Hasil analisis ragam menunjukkan bahwa berbagai macam mulsa berpengaruh tidak nyata terhadap jumlah anakan perumpun (anakan) Bawang Merah di tanah Ultisol. Rataan jumlah anakan perumpun Bawang Merah pada masing-masing perlakuan pengaruh berbagai macam mulsa dapat dilihat pada Tabel 3.

Tabel 3. Rataan Jumlah Anakan Perumpun (anakan) Bawang Merah Pengaruh Berbagai Macam Mulsa di Tanah Ultisol

\begin{tabular}{|c|c|}
\hline Perlakuan & Rata-Rata (anakan) \\
\hline M0 & 7,13 \\
M1 & 7,13 \\
M2 & 7,00 \\
M3 & 6,63 \\
M4 & 6,04 \\
\hline KK = 18,15\% \\
\hline
\end{tabular}

Keterangan : Perlakuan tidak berpengaruh nyata terhadap jumlah anakan (anakan) $(\mathrm{P}>0,05)$.

Tabel 3 menunjukan bahwa rataan jumlah anakan yang dihasilkan perlakuan berbagai macam adalah sebesar 6,04 - 7,13 anakan dan berpengaruh tidak nyata terhadap tanaman bawang merah di tanah ultisol secara statistik $(\mathrm{P}>0,05)$. Hal ini diduga berbagai mulsa yang diberikan mengalami peningkatan laju evaporasi sehingga jumlah air tanah yang tertinggal dalam tanah menjadi berkurang sehingga tanaman mengalami cekaman air

Rataan jumlah anakan bawang yang dihasilkan pada penelitian yaitu $6,04-7,13$ batang juga sangat rendah jika dibandikan dengan deskripsi tanaman (lampran
4) yaitu 9- 17 anakan. Hal ini diduga karena pada saat tanaman kekurangan air atau dalam kondisi cekaman air menyebabkan tanaman menjadi stress, yang berpotensi menyebabkan tekanan biologis (baik proses fisiologis maupun aktifitas fungsional) pada organisme hidup yang disebabkan oleh faktor lingkungan (Zlatev dan Lidon, 2012 dalam Zulkarnain, dkk., 2017). Lebih lanjut dikatakan Rahayu dan Berlian (1999) bahwa bawang merah tidak tahan kekeringan karena akarnya pendek, selama pertumbuhan dibutuhkan air yang cukup banyak.

\section{Bobot Basah Umbi Per Rumpun (gram )}

Berdasarkan hasil analisis ragam menunjukkan bahwa berbagai macam mulsa berpengaruh tidak nyata terhadap bobot basah umbi perumpun (gr) Bawang Merah di tanah Ultisol. Rataan bobot basah umbi perumpun Bawang Merah pada masing-masing perlakuan pengaruh berbagai macam mulsa dapat dilihat pada Tabel 4.

Tabel 4. Rataan Bobot Basah Umbi Perumpun (gr) Bawang Merah Pengaruh Berbagai Macam Mulsa di Tanah Ultisol

\begin{tabular}{|c|c|}
\hline Perlakuan & Rata-Rata (gr) \\
\hline M0 & 19,13 \\
M1 & 20,44 \\
M2 & 21,25 \\
M3 & 19,38 \\
M4 & 16,44 \\
\hline KK = 16,74 \% \\
\hline
\end{tabular}

Keterangan : Perlakuan tidak berpengaruh nyata terhadap bobot basah umbi perumpun (gram) $(\mathrm{P}>0,05)$.

Berdasar Tabel 4 di atas dapat dijelaskan bahwa bobot basah umbi perumpun yang dihasilkan perlakuan berbagai macam berpengaruh tidak 
nyata terhadap tanaman bawang merah di tanah ultisol secara statistik $(\mathrm{P}>0,05)$. Hal ini diduga berbagai mulsa yang diberikan belum mampu memodifikasi faktor lingkungan, kelembaban, dan kadar air yang terus bekurang sehingga penyerapan unsur hara oleh tanaman juga terganggu sehingga bobot basah bawang merah yang dihasilkan sama.

Secara numerik memang terlihat ada perbedaan pengaruh, tetapi secara statistik tidak memperlihatkan pengaruh yang nyata. Hal ini diduga mulsa sebagai perlakuan pada tanah ultisol tidak merespon pertumbuhan dan produksi tanaman bawang merah, karena masih banyak faktor-faktor yang perlu diperhatikan seperti suhu udara, angin, cahaya matahari dan curah hujan. Apabila faktor lingkungan kondusif untuk pertumbuhan tanaman, maka fotosintat yang dihasilkan juga meningkat sehingga alokasi biomassa kebagian yang dipanen juga relatif lebih besar.

Menurut Sunanto (2008), pemberian mulsa terhadap budidaya tanaman hanya berpengaruh fisik tidak memberi pengaruh kimia pada tanah. Pengaruh fisik mulsa bagi tanaman masih dibawah pengaruh tanah ultisol sebagai tempat penanaman. Pada tanah ultisol keuntungan mulsa untuk mengurangi penguapan kurang berdampak karena tanah ultisol memiliki kapasitas menahan air tinggi. Budidaya tanaman hortikultura dilahan ultisol tergantung pada pengelolaan air, tanah dan jenis tanaman hortikultura yang dibudidayakan.

Rahayu dan Berlian (1999) menyatakan sifat kimia tanah yang sesuai untuk tanaman bawang merah yaitu $\mathrm{pH}$ tanahnya 5,5-7. Pemberian mulsa pada tanaman bawang merah merespons pertumbuhan dan produksinya apabila $\mathrm{pH}$ tanahnya normal $(6,6-6,8)$. Lebih lanjut dikatakan Rahayu dan Berlian (1999) jika pH dibawah 5,5 banyak mengandung garam Aluminium (Al). Garam ini bersifat racun sehingga menyebabkan tanaman menjadi kerdil dan ditanah yang terlalu basa dengan $\mathrm{pH}$ lebih dari 7, garam mangan (Mn) tidak dapat diserap oleh tanaman. Akibatnya umbi yang dihasilkan kecildan produksi tanaman rendah.

\section{Bobot Umbi Perhektar (Ton/ha)}

Berdasarkan hasil analisis ragam menunjukkan bahwa berbagai macam mulsa berpengaruh tidak nyata terhadap bobot umbi perhektar (ton/ha) Bawang Merah di tanah Ultisol. Rataan bobot umbi perhektar Bawang Merah pada masing-masing perlakuan pengaruh berbagai macam mulsa dapat dilihat pada Tabel 5 .

Tabel 5. Rataan Bobot Umbi Perhektar (ton/ha) Bawang Merah Pengaruh Berbagai Macam Mulsa di Tanah Ultisol

\begin{tabular}{|c|c|}
\hline Perlakuan & $\begin{array}{c}\text { Rata-Rata } \\
\text { (Ton/Ha) }\end{array}$ \\
\hline M0 & 8,50 \\
M1 & 9,08 \\
M2 & 9,44 \\
M3 & 8,61 \\
M4 & 7,31 \\
\hline KK = 16,74 \% \\
\hline
\end{tabular}

Keterangan : Perlakuan tidak berpengaruh nyata terhadap bobot umbi perhektar (ton/ha) $(\mathrm{P}>0,05)$.

Berdasar Tabel 5 di atas dapat dijelaskan bahwa anakan yang dihasilkan perlakuan berbagai macam berpengaruh tidak nyata terhadap tanaman bawang merah di 
tanah ultisol secara statistik $(\mathrm{P}>0,05)$. Hal ini diduga berbagai mulsa yang diberikan belum dapat memberikan kondisi lingkungan yang optimal, terutama suhu udara dan suhu tanah yang berperan penting dalam berbagai proses fisiologi (fotosintetis, transpirasi dan respirasi).

Van $\begin{gathered}\text { Seperti yang dikemukakan } \\ \text { Iersel (2003) dalam }\end{gathered}$

Wisudawati (2016), bahwa peningkatan suhu hingga batas optimal dapat menaikkan hasil bersih fotosintesis, tetapi pada batas suhu maksimal hasil tersebut menurun tajam karena terjadi peningkatan respirasi. Pada suhu optimum bagi mikroba efektivitasnya meningkat untuk mengurai bahan organik menjadi unsur yang dapat diserap oleh akar tanaman.

Menurut Levitt (1980) dalam Sinaga (2007), bahwa tanaman yang mengalami stress air (dehidrasi) akan merusak perkembangan sel-sel tanaman yang mengakibatkan pertumbuhan tanaman terhambat, stomata mengkerut (terhambatnya fotosintesis) terhambatnya partumbuhan mesofil yang mengakibatkan kehilangan ruang interselular dan metabolisme terganggu, perkembangan sel terhambat yang mengakibatkan proses fotosintesis dan respirasi terhambat.

Rataan bobot basah umbi perhektar yang dihitung pada saat panen yaitu 65 hari setelah tanam juga sangat rendah yaitu hanya mencapai 7,31 - 9,44 ton/ha sedangkan deskripsi tanaman mencapai 17,6-22,3 ton/ha hal ini karena unsur hara yang tidak tersedia sehingga hasil bawang merah sangat rendah. Menurut Rahayu dan Berlian (1999) tanaman bawang merah menyukai tanah yang subur, gembur dan banyak mengandung bahan organik. Tanah yang subur akan mendorong perkembangan umbi sehingga hasilnya besar-besar lebih lanjut dikatakan bahwa bawang merah hendaknya ditanam pada tanah yang mudah meneruskan air, aerasinya baik dan tidak becek.

\section{KESIMPULAN DAN SARAN}

\section{Kesimpulan}

Berdasarkan hasil penelitian dan pembahasan dapat diambil kesimpulan, yaitu sebagai berikut :

1. Penggunaan berbagai macam mulsa berpengaruh tidak nyata terhadap semua parameter yang diamati yaitu : tinggi tanaman (cm), jumlah daun (helai), jumlah anakan perumpun (anakan), bobot basah umbi perumpun (gram) dan bobot umbi per hektar (Ton/ha) tanaman bawang daun.

2. Dari hasil percobaan dengan pemakaian berbagai mulsa belum memberikan perbedaan terhadap pertumbuhan hasil tanaman bawang merah.

\section{Saran}

Untuk mendapatkan produksi tanaman bawang merah yang optimal disarankan untuk penelitian lebih lanjut terhadap berbagai macam mulsa yang lain di tanah ultisol.

\section{DAFTAR PUSTAKA}

Badan Pusat Statistik Jambi. 2016. Produksi Tanaman Ba-wang Merah Provinsi Jambi

Chairumansyah. 2010. Keuntungan Penggunaan Mulsa Plas-tik. http://binatani.blo- 
gspot.com/2010/03/keuntung

an-penggunaan-mulsa-

plastik.html. Diakses tanggal

24 Desember 2017.

Dariah, A. 2007. Konservasi Tanah pada Lahan Tegalan. Buku Bunga Rampai KTA 12-07. http://balittanah.litbang.depta n.go.id/dokumentasi Diakses 26 Agustus 2018.

Ekowati, V.D, Koesriharti dan Tatik, W. 2017. Pengaruh Mulsa Dan Sumber Unsur Hara Nitrogen Pada Pertumbuhan Dan Hasil Tanaman Bawang Merah (Allium cepa var. ascalonicum). Jurnal Produksi Tanaman Vol. 5 No. 4, April 2017: 625 - 631 ISSN: 2527-8452. Diunduh 15 Agustus 2018.

Gardner, F.P., Pearce dan R.L., Mitchel, 1991. Fisiologi Tanaman Budidaya. Diterjemahkan oleh Herawati Susilo. UI Press. Jakarta.

Hanhim. 2014. Pengaruh Pemberian Mulsa Jerami Padi Dan Kepadatan Tanah Terhadap Pertumbuhan Dan Produksi Padi Gogo (Oryza sativa L). Skripsi Departemen Ilmu Tanah Dan Sumberdaya Lahan Fakultas Pertanian.IPB. Bogor .

Mayun, I.A. 2007. Efek Mulsa Jerami Padi dan Pupuk Kandang Sapi terhadap Pertumbuhan dan Hasil Bawang Merah di Daerah Pesisir. Agritrop, 26 (1) : 33 - 40 (2007)issn : 02158620. Diunduh 15 Agustus 2018
Prasetyo, B.H dan Suridakarta D.A. 2006. Karakteristik, Potensi, dan teknologi pengelolaan tanah ultisol untuk pengembangan pertanian lahan kering di Indonesia. Jurnal Litbang Pertanian, 25(2): (hlm. 41)

Priatna, Apep Rudi. 2012. Mulsa. Posted by Apep Rudi Priatna on

Rahayu, E, dan Berlian,N. 1999. Bawang Merah. Penebar Swadaya, Jakarta. $89 \mathrm{hlm}$.

Samiati, Bahrun A. dan L.O. Safuan. 2012. Pengaruh Takaran mulsa Terhadap Pertumbuhan Dan Produksi Sawi (Brassica juncea L.). Berkala Penelitian Agronomi Oktober 2012 Vol. 1 No. 2. ISSN: 2089-9858. Diunduh 25 Agustus 2018.

Sumarni, N. dan Hidayat A. 2005. Budidaya Bawang merah. Balai Penelitian Tanaman Sayuran. Jakarta Selatan.

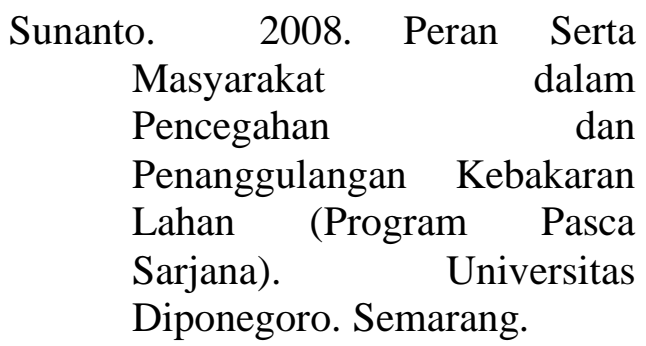

Syarfianda, 2015. Respon Pertumbuhan Dan Hasil Tanaman Bawang (Allium ascalonicum L.)Sebagai Efek Pemberian Pupuk Kompos Kirinyuh (Chromolena odorat) Dan Pupuk Npk. Fakultas 
Pertanian, Universitas Syiah Kuala.

Wisudawati. D. M. Anshar dan Iskandar. L. 2016. Pengaruh Jenis Mulsa Terhadap Pertumbuhan dan Hasil Bawang Merah (Allium ascalonicum Var. Lembah Palu) Yang Diberi Sungkup. e-J. Agrotekbis 4 (2) :126133, April 2016 ISSN : 23383011. Diunduh 24 Agusutus. 2018

Zulkarnain, M.F., Lienjte. K.T dan J. M. Mawara. 2017. Analisis Ketersediaan Air Untuk Tanaman Tomat (Lycopersicum esculentum Mill) Dan Jagung (Zea mays L.). Di Tonsewer. https://ejournal.unsrat. ac.id/index.php/cocos/article/ view/15882. Diunduh 21 Agustus 2018 